\title{
PRINCIPLES AND PRACTICES OF CAR SERVICE REGULATION
}

\author{
By H. E. BYram
}

The problem of car service may be stated briefly as the formulation of a plan whereby freight car equipment may be made to perform the maximum of service in a unified system of transportation with the minimum of sacrifice of the rights of the owner of the cars. Under this definition the subject presents two distinct phases, one economic, the other financial.

In what manner shall car service be regulated in the public interest so that each unit shall furnish the greatest amount of transportation?

How shall it be regulated so that rights of possession and compensation for use will be equitably adjusted as between the owner and the user of the equipment?

The managers of the railroads and of other concerns which own the cars must consider the problem from the standpoint of the interests of their own concerns; but they must also consider it from the standpoint of the public welfare. The governmental regulating authorities are apt to consider the problem primarily from the standpoint of the public; but they should not ignore the interests and the rights of the companies which have invested capital in cars. Therefore, while regulating authorities may put more emphasis on the interests and rights of the public, and the railway managers may put more emphasis on the interests and rights of the individual companies, there really is no fundamental difference between the problem of car service as it presents itself to the railway manager and to the regulating body; and there can be no substantial difference between their solutions of it, if each gives due weight to both the private and the public rights and interests involved. It will be desirable to review the methods the railways themselves have used in dealing with the problem of car service before discussing the problem presented by regulation of car service.

Even under the system of car interchange in force before normal conditions were disturbed by the entrance of the country into the Great War, the railway industry of the United States, in its han- 
dling of car equipment, bore some of the aspects of a single system. The complexity of the problem of car service, even under normal conditions, had constantly grown greater. It had been influenced by the number of conflicting interests involved, which had increased in number through the advent of new and the dissolution of previously consolidated organizations; by the great extent of territory through which car equipment was handled; by the development of specialization in the adoption of equipment for the handling of particular commodities; but more than all by the aggregate increase in the demands of industry for adequate equipment facilities, the occasional scarcity of equipment, and a recognition of the economic necessity, under any condition, of securing the best possible utilization of existing equipment. However important the problem may be under normal conditions, its importance is greatly magnified when, as now, it is essential that every item of transportation equipment be made to perform its full part in carrying out the purposes for which we are engaged in the war.

\section{Elements of the Problem}

The general term "car service" is commonly used to designate all that concerns the handling of the car as a vehicle of transportation, not only as between one railway and another, but also as between railways and the shipper or consignee. On June 30, 1916, according to the statistics of railways compiled by the Interstate Commerce Commission, there were in service in this country approximately two and one-half millions of freight cars. Of these, about $2,300,000$ were owned by railway companies, and the rest by private car line companies, mining companies, etc. The number of the different classes of cars owned by the railways were as follows:

Box cars

Flat cars

Coal cars

Stock cars

Tank cars

Refrigerator cars

Other cars

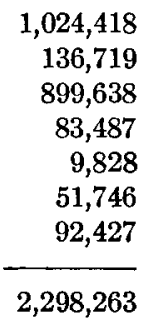

$1,024,418$

136,719

83,487

9,828

51,746

2,427

$2,298,263$

Total

The mileage of all railways in the United States on the same date was 259,210 miles. There are then on the railways of the 
United States approximately 9 freight cars per mile of railway. The ownership of these cars, excluding those of private ownership, is in the hands of about 1,000 railway companies. The number owned by each company varies from a few cars to upwards of 250,000 .

\section{Joint Use of Car Equipment}

The plan under which railways have for many years used equipment interchangeably is the result of voluntary action on the part of railways themselves to the end of securing greater facility of operation and hence more efficient service. The Interstate Commerce Commission has always recognized the commercial necessity of through shipments, and consequently the movement of cars over other than the owning roads; and, indeed, the original Act to Regulate Commerce seems to recognize it, though in a negative way. The Act, approved on February 4, 1887, provides that

It is unlawful . . . . to enter into any . . . . agreement . . . . to prevent . . . . the carriage of freight from being continuous from place of shipment to place of destination . . . . by carriage in different cars, unless . . . . such interruption was made for some necessary purpose . . . and without intent to interrupt continuous carriage, etc.

In a decision ${ }^{1}$ rendered November 13, 1911, the Commission affirmatively defined the duties of the carriers with reference to a unified service:

The railroads of the country are called upon to so unite themselves that they will constitute one national system; they must establish through routes, keep these routes open and in operation, furnish all the necessary facilities for transportation, make reasonable and proper rules of practice as between themselves and the shippers, and as between each other.

\section{Why There Is a Problem}

If cars performed service only upon the road by which they are owned, there would be no problem of car service regulation in the sense in which it now exists. Between railways, as distinguished from those phases of the problem that arise between railways on the one hand and shippers and consignees on the other, the questions to be settled are predicated upon the ownership of the cars and their service upon other than the owning line. For this reason, the problem of car ser vice is of chief importance in times of scarcity

${ }^{1}$ Missouri \& Illinois Coal Co. v. Illinois Central, 22 I. C. C. 39. 
of equipment to meet the requirements of shippers-"car shortage." Since "car shortage" does not always mean a deficiency of equipment upon all the railways considered as one transportation system, but frequently means only that cars wanted in the West are detained in the Fast, or vice versa, it is clear that some definite plan of distribution should be determined upon for securing the maximum of service from each car with the minimum of infringement upon the rights of ownership.

A fundamental principle has been laid down by the American Railway Association that every railroad is entitled to the use of cars equal to its ownership. As a financial proposition it would seem that a road is entitled either to the service of its owned cars, in which case it would be expected that their earnings would pay interest on the investment and a fair average yearly earning plus an amount sufficient to keep them in repair and to provide for depreciation; or, if the cars are in the service of or detained on other roads, to receive from the holding road compensation sufficient to cover these several items. This is, in its simple form, the end to be attained.

It would seem, perhaps, that the application of a fixed mileage or per diem charge for the service or detention of a car upon a foreign road should afford an equitable basis for settlement between roads in all cases. Both systems have been tried. Neither has proved wholly satisfactory. Up to 1902, except in a few experimental instances, the only basis upon which a road received payment for the use of its cars on a foreign road was at a rate varying in different years from one and one-half cents to three-fourths of a cent per mile. The main objection to the plan was that charges did not accrue when a car was not moving. It might conveniently be used as a warehouse while cars belonging to the road holding it were engaged in more profitable service. It is not necessary to mention the possibility of error in reporting mileage. However, it is much easier to check up the service of a car by days than by miles; and in 1902 the railways constituting the American Railway Association adopted per diem rules, by which the owning road is paid at a fixed daily rental while its cars are in possession of other roads, which with numerous changes in rate and conditions of application have since remained the basis of settlement of car service between railways. 


\section{Two Views of Car Service}

With the development of the American railway system there have developed two schools of opinion as to the rights of railways to the possession and use of rolling stock. One rests on the basis that all car service rules that have ever been in force, except as they may have been locally modified within recent months to meet emergency conditions, recognize the fact that ownership of a car involves a right to its prompt return after it has performed its immediate function in the through service on which it had been forwarded. The second school of opinion assumes that the creation of through routes and joint rates has in effect created a pool of all cars used in such service, and that existing rules do not effectually regulate the service in the pool.

The Commission on Car Servise of the American Railway Association, in formulating the two views above set forth, reported in March, 1916, that, whatever the solution of the problem, the efficiency of the rules in force had not been proved because of the lack of their enforcement. It then gave notice that, beginning on June 1, 1916, it would act not only as a mediator in disputed matters, as heretofore, but also would enforce the rules by the imposition of the penalties the rules authorized. The Commission found it had not sufficient authority to deal with the existing situation. The same emergency called for putting into effect certain changes in the rules and finally for the adoption of a revised code of rules, which in turn has been upset in their operation by the transportation necessities of a nation actively engaged in war.

Car equipment is conveniently considered in two general classes. Special equipment, for example, open cars, ordinarily involves an empty return movement. Under normal conditions its service seems to have been fairly regulated by the rules in force. "Legal tender" equipment, for example, box cars, may be and ordinarily is, loaded at any time at any point in any direction when there is traffic. The use of this class of equipment could not be effectively regulated under the rules formerly in force governing special equipment, because of a general recognition of the economic waste involved in returning an empty box car directly to its home road when by a diversion it could advantageously be loaded for movement in another direction. There has therefore been in effect for years a practically unregulated pool of this equipment. The result has been 
that in times of unusual movement of traffic roads that had provided a seemingly adequate supply were unable to furnish cars, while roads with a less adequate supply were able to meet all demands because of their tenacity of hold upon foreign cars. The unregulated pool is therefore particularly unjust during times of car shortage to originating lines that have provided their quota, or more than their quota, of cars. It is likewise unjust to the public served by those lines which, without fault of their own, have been short of cars. In times of surplus, the unregulated pool is a source of injustice to distributing lines, because they are unable to get rid of the surplus equipment and are forced to pay per diem charges.

The situation and the remedy were summed up by the Commission on Car Service in 1913. The following paragraphs are extracted from its report of that date:

To be just to the railroads themselves and to the public generally, this pool should be regulated, to the end that there shall be secured to every road the use, when it needs them, of its quota of "legal tender" equipment (whether its own or the equivalent in foreign cars) or, in the alternative, compensation in money for the difference. Such regulation can be made effective only by the abandonment of the right to physical return to the owner of its own cars, and the substitution of the right to possession and use by each line of "legal tender" cars in kind equivalent to the cars by it owned and contributed to the pool.

The objections to recognizing a box car pool in the past have rested largely on the desire of roads which have supplied their quota of "legal tender" equipment, and have maintained it on high standards, to be assured of the use of cars measuring up to their standards. The answer is, that in practice existing car service rules have not secured this result so far as box cars are concerned.

It is true that the force of the objections to a box car pool is augmented by the inequalities in construction, in strength, equipment, capacity and cost of maintenance, of the box cars contributed to this irregular pool by the different roads. But it is also true that these inequalities are gradually disappearing. The adoption of a standard box car should remove the last objection to such a pool and would besides be attended with a considerable saving in cost of building.

While there was, as before stated, no fair opportunity to test completely the effect of enforcement of the car service rules formerly in force, the new system adopted since this country entered the war seems to have tended to demonstrate the efficiency of pooling in securing a maximum of service from each car and a minimum of de- 
lay to the shipper in meeting requisitions. During the six months ending with September, 1917, the railways handled 14 per cent more freight than in the corresponding months of last year with substantially no increase in equipment. Though establishing a virtual pool of box cars, the new rules recognize the right of the owner to the prompt return of special equipment and this is doubtless for the good of the service as well as a recognition of ownership rights. The roads that have an adequate supply of special equipmentcoal, refrigerator or automobile cars-doubtless have them because of the amount of traffic originating on their roads requiring such facilities. It would neither be fair to them nor in the interests of the highest efficiency, except in emergency, to use this equipment for purposes for which the ordinary box car would serve as well or better. Recently, however, a pool of the coal cars of the Eastern Railways has been temporarily established.

The principal features of the system developed by the Commission on Car Service under the authority conferred upon it as a war measure and acting in coöperation with the Interstate Commerce Commission have been the transfer of equipment from one section of the country to another where there was a greater need for it; and the success of its efforts to secure a greater efficiency of movement and loading of cars. Local shortages have been reduced by the transfer to needy localities of the required equipment collected in comparatively small lots from a large number of roads. More than 200,000 cars have been thus transferred. Until the usual increase in volume of traffic in the late fall and the inevitable slowing down of movement in the early days of winter, this system of handling by one authority had operated to reduce unfilled requisitions for cars from 148,000 cars on May 1, to 34,000 on September 1, though, as before stated, 14 per cent more traffic had been handled than during the corresponding months of the previous year. The increase in traffic handled was partly due, also, to the increased mileage per car per day, in which the efforts of the railways were greatly assisted by the coöperation of shippers, as they were also in the loading of cars more fully to capacity. So far as box cars are concerned, the present rules and the flexible system under which they are in force seem to afford the best means available for handling car service. The designation, from time to time, of commodities that may or may not be transported in open cars or special equip- 
ment, has a tendency to minimize the economic waste involved in the usual empty return movement. Though designated as emergency measures, the rules and their application are based on efficiency of service.

The power conferred upon one body to regulate car supply as exigencies may require seems to provide for fulfilling the conditions of the economic phase of the question; and the right of appeal concerning the handling and use of equipment by a foreign road affords means for equitable financial adjustment. The slogan of the service is: "In all cases, keep the cars moving, and settle differences of opinion afterward."

As already intimated, the Interstate Commerce Commission, by act of Congress on May 29, 1917, was given express authority to regulate car service. The act defines the term "car service" as including "the movement, distribution, exchange, interchange, and return of cars used in the transportation of property." It requires every carrier to "establish, observe and enforce just and reasonable rules, regulations and practises with respect to car service," and gives the Commission authority to "suspend the operation of any rules, regulations or practises then established with respect to car service for such time as may be determined by the Commission, and also authority to make such direction with respect to car service as in its opinion will best promote car service in the interest of the public and the commerce of the people."

In the administration of this law the Commission in July, 1917 , organized a division of car service, which, under the reorganization of the Commission, has been changed to the Bureau of Car Service. It is evident, however, that the Commission believes that the railways through their own Commission on Car Service have been doing all they could to secure the greatest efficiency in the use of cars; for its Bureau of Car Service has thus far devoted itself chiefly to coöperating with the railways' Commission on Car Service. The Interstate Commerce Commission says in its annual report for 1917:

Where occasion requires, orders or directions will issue under the car service act and directly to the carrier or the carriers directly concerned. Subject to this fundamental principle, the Commission is availing itself, and will continue to avail itself, of coöperative effort on the part of the carriers' Commission on Car Service. - . . The present is peculiarly a time for the avoidance of unnecessary expense and duplication of work, and it has seemed to the Commission desirable 
to utilize to the fullest extent all means for insuring maximum efficiency in the handling of cars.

That the spirit and manner in which the Commission has gone about its regulation of car service thus far have been effective in furthering the object it mentions - viz., "insuring maximum efficiency in the handling of cars" -is unquestionable. In periods of heavy traffic, such as the present when there are not enough cars to move all the freight, the great problems of car service, whether viewed from the standpoint of the managements of the railways, or that of the regulating authority, are, first, that of putting cars where they are most needed, and, second, that of securing the utmost service from each car. With equal information as to the conditions, the decision of the railways' Commission on Car Service and that of the Interstate Commerce Commission's Bureau of Car Service as to where cars are the most needed are pretty sure to be the same. Likewise, with the same information as to conditions, their decisions are pretty sure to be the same as to the best methods of securing the greatest efficiency in the utilization of cars. But it does not follow that government regulation of car service is superfluous. The railway man naturally looks at the problem from the railway standpoint. The representative of the government naturally looks at it from the standpoint of the public. Friendly coöperation between the representatives of the government and the officers of the railroads is desirable in order adequately to protect and promote the interests of both railways and public. 